University of Nebraska - Lincoln

DigitalCommons@University of Nebraska - Lincoln

1992

\title{
Plant Resistance to Insect Herbivores: A Field Test of the Environmental Stress Hypothesis
}

Svata M. Louda

University of Nebraska - Lincoln, slouda1@unl.edu

Sharon K. Collinge

Rocky Mountain Biological Laboratory, Gothic, Colorado

Follow this and additional works at: https://digitalcommons.unl.edu/bioscilouda

Part of the Ecology and Evolutionary Biology Commons

Louda, Svata M. and Collinge, Sharon K., "Plant Resistance to Insect Herbivores: A Field Test of the Environmental Stress Hypothesis" (1992). Svata M. Louda Publications. 11.

https://digitalcommons.unl.edu/bioscilouda/11

This Article is brought to you for free and open access by the Papers in the Biological Sciences at DigitalCommons@University of Nebraska - Lincoln. It has been accepted for inclusion in Svata M. Louda Publications by an authorized administrator of DigitalCommons@University of Nebraska - Lincoln. 


\title{
PLANT RESISTANCE TO INSECT HERBIVORES: A FIELD TEST OF THE ENVIRONMENTAL STRESS HYPOTHESIS ${ }^{1}$
}

\author{
SvaŤa M. Louda AND SHARON K. COLlingE ${ }^{2}$ \\ School of Biological Sciences, University of Nebraska, Lincoln, Nebraska 68588-0118 USA and \\ Rocky Mountain Biological Laboratory, Gothic, Colorado 81224 USA
}

\begin{abstract}
We tested the hypothesis that environmental stresses decrease overall plant resistance to insect herbivory in the field and evaluated biochemical mechanisms proposed to explain insect response to stressed plants. To impose a stress treatment, we severed lateral roots and rhizomes of a native crucifer (bittercress, Cardamine cordifolia) and quantified plant and herbivore responses for treatment and control clones. Severing roots and rhizomes once, early in the growing season: (1) produced moderate, but detectable, changes in plant physiological traits, specifically greater transient leaf water deficits at midday $(P<.05)$ and elevated nitrate-nitrogen concentrations $(P<.05) ;(2)$ altered plant quality, by causing an increase in soluble carbohydrates $(P<.003)$, isoleucine concentrations in leaves $(P<.01)$, and possibly glucosinolate concentration $(P<.10)$, but made no differences in most primary nutrient concentrations, including total nitrogen, total free amino nitrogen, total amino acids, proline, and leaf water content; and (3) led to increased herbivory by chewing and leaf-mining $(P<.001)$, but not by sap-feeding, insect herbivores. Trends toward decreased plant stature and fruit reproduction were not significant after 1 mo. In addition to the significant effect of our treatment, we found extensive variation in the magnitude of response to stress and herbivory among replicates. We hypothesize that environmentally induced physiological variation among plants within a plant population commonly distributes insect herbivory disproportionately onto a subset of the individuals, and in so doing influences the demography, distribution, and evolution of that plant population.
\end{abstract}

Key words: Cardamine cordifolia; environmental stress; herbivore-plant interaction; insect herbivory; insect-plant; plant-animal interactions; stress.

\section{INTRODUCTION}

Variation in herbivore damage among plants within a population is one of the most striking, consistent, and yet relatively unexplored, features of plant-insect interactions (Harper 1977, Crawley 1983, Denno and McClure 1983, Louda et al. 1990). Such individual variation may be one of the most critical aspects in both the population dynamics (Louda 1982,1983) and evolution (Thompson 1988) of plant-insect systems.

Many factors could account for such variation. Among those factors, the potential stresses imposed by water deficits, nutrient imbalances, or pollutants in the environment have been hypothesized to improve plant quality and, thus, decrease individual plant resistance to insect herbivory (see White 1969-1984, Tingey and Singh 1980, Hughes et al. 1982a, $b$, Cates et al. 1983, Louda 1986, 1988, Mattson and Haack 1987a, $b$, Heinrichs 1988, Hughes 1988, Jones and Coleman 1991). However, some observations contradict this generalization (e.g., Miles 1982b, Myers 1985, Waring and Price 1988). Since few tests of this hypothesis have

\footnotetext{
${ }^{1}$ Manuscript received 11 October 1989; revised 25 February 1991; accepted 27 February 1991.

${ }^{2}$ Present address: Graduate School of Design, Program in Landscape Ecology, Harvard University, Cambridge, Massachusetts 02138 USA.
}

been done for native plants in the field, especially for nonwoody species, we designed this study to do so.

By "stress" we mean environmental conditions or changes that have measurable negative effects on plant traits or performance (e.g., Hsiao 1973, Boyer 1982). Water deficit stress, for example, has been defined as the induction of turgor pressure below the maximal potential pressure (Fitter and Hay 1981, Osmond et al. 1987). The magnitude of such stress is determined by the extent and the duration of deviation or deprivation. Hsiao (1973) proposed three functional levels for water stress: mild $=$ deficit of $<0.5 \mathrm{MPa}$, moderate $=$ deficit of 0.5 to $1.5 \mathrm{MPa}$, and severe $=$ deficit of $>1.5$ MPa. Here we estimate stress as the deviation in plant performance, compared to that of controls, in response to a specific experimental manipulation of growing conditions. In addition, we use other changes generally associated with stress, such as increased concentrations of nitrate-nitrogen and soluble carbohydrates in leaf tissues (Hsiao 1973, Mattson and Haack 1987a, b), to detect plant response and to index the degree of deviation compared to the performance of control plants.

Stresses on plant growth, such as reductions in the availability of soil water, could cause decreased plant resistance. Stress can increase the availability of nutrients (White 1969-1984, McNeill 1973, McNeill and Southwood 1978, Mattson 1980, Mattson and Haack 
$1987 a, b)$, decrease the concentrations of defensive compounds in leaves (Rhoades 1983, 1985, Gershenzon 1984, Mattson and Haack $1987 a, b$ ), or alter the ratio of nutrients to chemical defenses (Bazzaz et al. 1987). Alternately, however, stress can lead to increased plant resistance to insects. For example, higher concentrations of allelochemics are reported for some plants in harsh or stressful environments than in ones considered more benign for plant growth (e.g., Janzen 1974, McKey 1979, Edwards and Wratten 1983, Gershenzon 1984, Coley et al. 1985). Either response, however, would affect predictions of herbivore use and impact. Yet, little direct experimental evidence exists on the response of native plants to environmental variation and on insect herbivore response to environmentally induced physiological variation of native plants under field conditions.

The information available suggests a positive relationship, in general, between insect feeding damage and plant stress, i.e., for trees (e.g., Cates and Alexander 1982, Cates et al. 1983, Redak and Cates 1984, Mattson and Haack 1987a, b, Heinrichs 1988), for crops (see Mattson and Haack 1987a, b, Heinrichs 1988), and for the few indigenous herbaceous species studied to date (Lewis 1979, 1984, Louda et al. 1987a, $b, c$, Collinge and Louda 1988b, Louda 1988). Interestingly, much more evidence exists for such a relationship for trees and crops than for native herbaceous plants. This discrepancy could represent either a fundamental difference in insect-plant interactions caused by alternate plant life histories or by a lack of sufficient information on such interactions for herbaceous species in nature.

The purpose of our study was to test the stress hypothesis in the field, by experimentally evaluating a sequence of four essential assumptions that underlie it. As a model system, we used the interaction between a native, herbaceous crucifer, Cardamine cordifolia A. Gray (bittercress), and its three main insect herbivore guilds. The underlying predictions are as follows. First, imposition of moderate stress under field conditions should modify plant physiological status, as it does in laboratory studies, by decreasing plant water potential, transpiration or nutrient uptake and increasing leaf temperatures, stomatal resistances, or leaf nitrate-nitrogen concentrations. Second, associated changes in leaf tissues should improve the quality of those tissues for insect herbivores, either increasing the availability of primary nutrients or decreasing concentrations of potentially defensive compounds, such as the mustard oil precursors or glucosinolates. Third, altered leaf quality should lead to higher use and damage by insect herbivores. Consequently, fourth, damage should decrease plant growth and reproduction relative to that of less stressed control plants.

The evidence supporting the first prediction, that various environmental stresses generally cause several predictable physiological changes, is voluminous (e.g., Kozlowski 1968, 1984, Levitt 1972, Hsiao 1973, Hsiao et al. 1976, Oka and Pimentel 1976, Gershenzon et al. 1978, Tingey and Singh 1980, Turner and Kramer 1980, Bradford and Hsiao 1982, Hanson and Hitz 1983, Hsiao and Bradford 1983, Kramer 1983, Mattson and Haack 1987b, Cates and Redak 1988, Heinrichs 1988). The changes associated with moderate water, nutrient, mineral, temperature, and pollutant stresses include: (a) altered gene expression; (b) reduced cell expansion, cell wall synthesis, protochlorophyll formation, and protein synthesis; (c) lowered levels of nitrate reductase; (d) decreased stomatal opening and $\mathrm{CO}_{2}$ assimilation, usually causing increased leaf temperatures; (e) decreased osmotic potential via the accumulation of osmolytes, such as inorganic ions, amino acids and especially proline, sugars and sugar alcohols, and organic acids; and (f) increased concentrations of some plant natural products, including mustard oil glycosides (see Hsiao 1973, McNeill 1973, Mattson 1980, Gershenzon 1984, Mattson and Haack 1987a, b, Heinrichs 1988).

Evidence underlying the second prediction, that changes associated with moderate stress often modify plant tissues in ways that improve their quality for insects, is also abundant (e.g., Kennedy 1958, Kennedy et al. 1958, Wearing and van Emden 1967, van Emden and Bashford 1968, 1971, Wearing 1972a, $b$, Lewis 1979, 1984, Haglund 1980, McClure 1980, Wolfson 1980, 1982, Hughes et al. 1982a, b, 1983, Miles et al. $1982 b$, Mattson and Haack 1987a, $b$, Collinge and Louda 1988b, Holtzer et al. 1988, Hughes 1988). For example, increases in soluble nitrogenous compounds (amino acids, amides) and in free sugars (nonstructural carbohydrates) generally improve the nutritive potential of plant tissues for insects (McNeill 1973, Baskin and Baskin 1974, Fox and Macauley 1977, Mattson 1980, McClure 1980, Scriber and Slansky 1981, Scriber 1984, Slansky and Scriber 1985, Slansky and Rodriguez 1987). Moderate levels of stress appear essential to this response since severely stressed plants are not used by most insects and mites (Mattson and Haack 1987a, Dale 1988, English-Loeb 1989).

Finally, evidence for the first two predictions leads logically to the third one, of greater damage to moderately stressed plants, and the fourth one, of decreased plant growth and reproduction in response to increased herbivory (e.g., White 1969, 1984, Mattson and Haack $1987 a, b$, Heinrichs 1988). Tests of these predictions are rare.

This set of predictions may be particularly relevant for explaining patterns of damage in crucifer-insect interactions. For example, Dentaria diphylla was heavily damaged by insects when transplanted from forest to old field (Hicks and Tahvanainan 1974). Brassica nigra grown in the laboratory with lower soil water availabilities was preferentially used by Pieris rapae (Wolfson 1980, 1982). And, in our study system, greater insect damage occurs on bittercress plants: (1) growing naturally or experimentally in the sun vs. in the adjacent willow shade (Chew 1977, Louda and Rodman 1983a, 


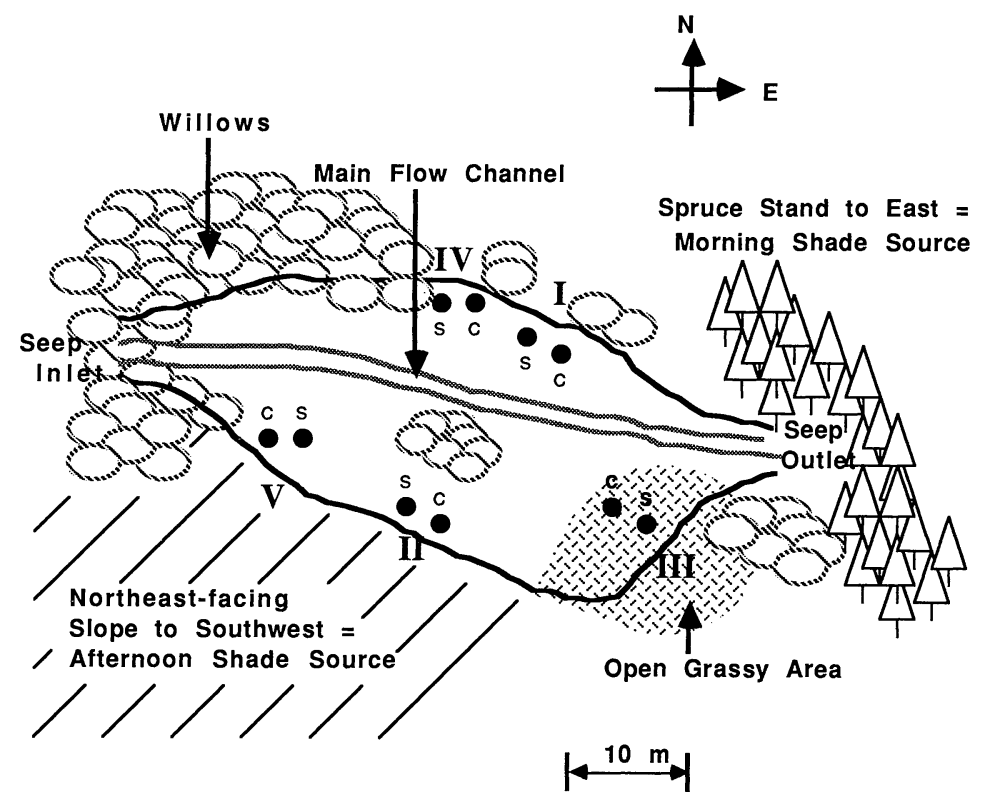

Fig. 1. Schematic map of the site (Main site), showing the distribution of the paired clones, comprising each replicate, within the population.

$b$, Collinge and Louda 1988a, $b$; S. M. Louda, unpublished manuscript); (2) on dry vs. on wet, portions of short soil moisture gradients (Louda and Rodman $1983 b$, Louda 1988); (3) on experimentally potted + flooded ramets (Louda 1986); and (4) on chemically stressed treatments (Louda 1988). In addition, evidence on specific mechanisms has shown that total insect damage generally increases in our crucifer-crucivore system as: (1) glucosinolate concentrations decrease (Louda and Rodman 1983a, $b$, and in Bowers 1988), (2) nitrate-nitrogen concentrations increase (Louda 1988; S. M. Louda and J. E. Rodman, unpublished data), and (3) soluble carbohydrate concentrations increase (Collinge and Louda 1988b, Louda 1988).

Additionally, there is conflicting evidence on the role of water stress in crucifer-crucivore interactions. In contrast to the laboratory results (Wolfson 1982), oviposition and feeding by Pieris rapae were not greater on cabbages that were grown in pots at lower water availabilities (Miles et al. 1982b, Myers 1985). The next obvious step, which we take here, is to experimentally evaluate both the response of the plant and of the insect herbivores to the imposition of moderate stress under natural field conditions.

\section{MeThodS \\ Study system}

We conducted the study at the Rocky Mountain Biological Laboratory, in the Elk Mountains of the central Rocky Mountains, Colorado (38 $8^{\circ} 7^{\prime} 56^{\prime \prime} \mathrm{N}$, $106^{\circ} 59^{\prime} 12^{\prime \prime} \mathrm{W}$ ). The vegetation consists of stands of willows, aspen, and spruce, interspersed with bunchgrass (Festuca thurberi Vasey) meadows (Langenheim
$1955,1962)$. The growing season in this area normally extends from late May to early September (Langenheim 1962, Chew 1975, Louda and Rodman 1983a). Our study was done at the "Main Site" (Site 1) of previous work (see Louda and Rodman 198B $a, b$, Rodman and Louda 1984, 1985, Collinge and Louda 1988a $b$ ), where bittercress occurs in a small, partly shaded ravine that receives run-off from a continuous snowmelt seep (Fig. 1).

Bittercress is a medium-tall $(30-75 \mathrm{~cm})$, clonal perennial crucifer that occurs throughout the Rocky Mountains from Idaho and Wyoming, south to Arizona and New Mexico (Harrington 1954). Plants are locally abundant in moist soil, typically in the light shade of willows (Barrell 1969, Louda and Rodman 1983a). Growth begins immediately after snow melt, with additional vegetative growth occurring basally after flowering and fruiting are complete (S. M. Louda, unpublished data). Flowering occurs in July and fruits mature in August.

Over 28 species of phytophagous insects utilize bittercress in the study region (S. M. Louda, unpublished data). At our study site the ones inflicting the majority of the damage observed included: a native psyllid (Aphalara sp. nov., near A. nubifera Patch and A. confusa Caldwell); several curculionid weevils (Ceutorhynchus sp. nr. moznettei Fall, C. pusio Mannerheim, $C$. americanus Boheman, $C$. subpubescens LeConte, $C$. sp. nr. neglectus Blatchley, $C$. sp. nr. pusillus LeConte); a drosophilid leaf miner (Scaptomyza nigrita Wheeler); several chrysomelid leaf beetles (Phyllotreta sp. nr. ramosa, P. sp. nr. viridicyanea Chitt., Phaedon sp. nr. oviformis); and, the diamondback moth (Plutella xylo- 
stella (L.). All of these species are members of cruciferfeeding genera (Bonnemaison 1965, Root 1973). One advantage of this system is that the diamondback moth is the only cosmopolitan pest species present. Our field observations and preliminary feeding trials (S. M. Louda, unpublished data) suggest little use of the other common crucifers in the area by most of these Cardamine-feeding insects. Thus, the primary consumers of this crucifer are "adapted" natural enemies (sensu Pimentel 1961, Root 1973, Feeny 1977).

\section{Experimental protocol}

We paired clones of bittercress distributed around the large naturally occurring stand. Replicates varied in exposure (Fig. 1). We randomly assigned one of two treatments to each member of the pair: control or stress $(N=5$ pairs), in a randomized complete block design, with replicate pairs as blocks. Stress was imposed only at the beginning of the experiment (19 June 1985) by cutting rhizomes and lateral roots between ramets, 4$6 \mathrm{~cm}$ from root crowns, using a sharp knife. We disturbed the control clones (separated ramets and ran a blunt instrument along the soil surface) but did not actually cut roots. Severing peripheral roots has been used previously to study clonal integration (e.g., Hartnett and Bazzaz 1983) and ecological aspects of environmental stresses for trees (e.g., Cates and Alexander 1982, Cates and Redak 1988). We followed treatment response for 1 mo (18 July 1985). This interval was chosen as a compromise, to allow detection of chemical differences as well as herbivore responses. Most oviposition by insects occurs in June, and differential levels of damage have usually accumulated by mid-July (Louda 1984, Collinge and Louda 1988a, b, 1989). Concentrations of leaf chemicals decline throughout the season (Rodman and Louda 1984, 1985). Insect activity occurs early, but fruit set is generally not completed until late August.

We sampled characteristics and insect damage in the field: initially, after $2 \mathrm{wk}$, and after $1 \mathrm{mo}$. The plant characteristics measured were: ramet height; number of basal leaves; number of cauline leaves, including notation of missing and dead ones; length and condition of all leaves present; and, the number of flower buds, flowers and fruits. We use the sum of flower buds, flowers, and siliques (fruits) as an estimate of reproductive potential. We assessed insect use and damage by measuring total leaf area damaged (LAD), including leaf area mined (LAM), counting the number of mines (NOM), and recording the presence/absence of psyllid eggs and pitting damage for each leaf. Leaf area damaged (LAD) was caused by the chewing of weevils, leaf beetles, and moth larvae, and by the mining of the drosophilid flies. Feeding by the larvae of the fly Scaptomyza nigrita can be partitioned out as leaf area mined (LAM), and we did so since these larvae often cause the majority of feeding damage at wet sites (Collinge and Louda $1988 a, b$ ). Since we did not measure the size of individual mines, we estimated the average mine size on a leaf by dividing the area minded per leaf by the number of mines on each leaf (LAM/NOM: see Fig. 3C). Feeding and oviposition by sap-feeding insects, primarily the psyllid Aphalara sp. nov., caused aberrant cell development and damage to leaves and stems that we refer to as "pitting" (J. R. Fleming and S. M. Louda, personal observations and unpublished manuscript). By recording all information by leaf position on each ramet, we could examine the distribution of damage among leaves within ramets as well as compare the distribution of damage between treatments.

To evaluate plant physiological response to our treatment, we measured: dawn and midday leaf water potentials, as well as midday stomatal resistances and leaf temperatures. We measured leaf water potentials using a Scholander Pressure Chamber (Scholander et al. 1965), and the other leaf parameters with a steadystate, null balance porometer (LI-COR 6000). Leaves used for physiological measurements were on ramets of the clone that were not used for measurements of insect damage and plant growth. Data on physical parameters include published climatological information for Crested Butte, Colorado (NOAA 1985) and measurements taken every 2 wk of photosynthetically active radiation (PAR), relative humidity, and air temperature. We estimated soil moisture content gravimetrically for replicate soil samples in each treatment.

At the end of the experiment (19 July 1985), we also measured plant chemical response by analyzing leaf samples for: leaf water content; total Kjeldahl nitrogen; free amino (ninhydrin) nitrogen, including the proportion of beta-amino nitrogen estimated as proline equivalents; individual amino acid concentrations; water-soluble nitrate-nitrogen; total nonstructural carbohydrates; and, isothiocyanate-yielding glucosinolate concentrations. Ratios of primary to secondary compound concentrations were calculated from these data. Foliage samples were collected for each replicate $(N=$ 5 ramets/treatment), placed into plastic bags containing cold water, returned to the laboratory, measured, and preserved within $2 \mathrm{~h}$. We boiled leaves to be analyzed for glucosinolates for $5-10 \mathrm{~min}$ in $70 \%$ methanol (Rodman 1978). Leaves for nitrogen and carbohydrate analyses were weighed, frozen in liquid nitrogen, lyophilized, and stored over desiccant until they were ground for analyses ( $425 \mu \mathrm{m}$ mesh sieve).

Standard analytical methods were used for: (1) total Kjeldahl nitrogen (Plant and Soils Analytical Lab, Agronomy Department, University of Nebraska-Lincoln; Bremner 1966, Isaac and Johnson 1976); (2) ninhydrin-detectable free amino nitrogen, as milligrams per gram dry mass of leucine and proline equivalents (Moore and Stein 1954); (3) high-pressure liquid chromatographic (HPLC, pico-tag) estimates of the concentration of 18 amino acids, (4) nitrate-nitrogen (Har ris Laboratories, Lincoln, Nebraska; Cataldo et al. 
1975); (5) total nonstructural carbohydrates (Palmer Laboratories, Agricultural Experiment Station, University of Alaska, Palmer, Alaska; Smith 1969); and (6) gas chromotographic estimates of the concentrations of the five isothiocyanate-yielding glucosinolates (IYG) common in bittercress (M. A. Blua, San Diego State University, 1984 and personal communication; Rodman 1978, Blua and Hanscom 1986).

We used multivariate analysis of variance to analyze overall insect and plant responses to the treatment, since many of the dependent variables of plant response and herbivore response were interrelated. All except one of the MANOVA models for insect and for plant responses were significant, but the model for overall chemical response was not $(P<.12)$. We examined the data for insect and plant response further using two-way ANOVA of treatment, replicate pair, and interaction effects in the component variables of plant and insect response on each date. We used error mean square for all variance ratios (SAS Type III sum of squares; Sokal and Rohlf 1981, Wilkinson 1986). Chemical differences at the end of the 1-mo experiment (18 July) were analyzed further using one-way ANOVA by treatment. Physical variation was analyzed using two-way ANOVA by treatment and date (1 July and 18 July). In all analyses we used square root transformed values $(Y+3 / 8)$ of counts, $\log (Y+1)$ values of linear and area measurements, and arcsine-transformed values for proportions (Sokal and Rohlf 1981).

Insect damage response variables for each leaf, averaged for all leaves on each ramet $(N=5$ ramets per treatment per date) were: leaf area damaged (LAD) per leaf, leaf area mined (LAM) per leaf, and number of mines (NOM) per leaf. Cumulative damage estimates were: the sum over all leaves on a ramet (LAD, LAM), or the proportion of leaves on the ramet with psyllid pitting or eggs, or drosophilid mines. The cumulative measures are most relevant for evaluation of insect effect on plant performance, but selected measures are presented on a per leaf basis to allow comparison with previously published work. Plant response variables analyzed were: ramet height, number of basal leaves, number and length of cauline leaves, number of leaves missing or dead, and fruit (=silique, =pod) production per ramet. As an estimate of potential fruit and seed reproduction we summed the number of flower buds, flowers, and fruits observed. Chemical response variables were concentrations of total Kjeldahl nitrogen, total amino acids (high-pressure liquid chromatography, HPLC), nitrate-nitrogen, total nonstructural car bohydrates, and isothiocyanate-yielding glucosinolates.

\section{RESULTS}

Overall, our results are consistent with the first three predictions of the stress hypothesis for variation in plant resistance to adapted insect herbivores, but not with the fourth. We found that cutting rhizomes and roots: (a) produced a moderate, but detectable, change in plant physiological condition (prediction 1); (b) altered plant quality by causing elevated levels of isoleucine, sugars, and possibly glucosinolates in treated plants (prediction 2); and (c) led to increased herbivory by chewing and mining insects (prediction 3). However, leaf production increased in the stress treatment. So, the predicted decreases in plant performance (prediction 4), which were observed as trends in leaf survival and fruit production, were not statisically significant after $1 \mathrm{mo}$.

\section{Environment}

Physical environmental conditions were similar for the two treatments (Table 1), as expected for adjacent clones. Light intensities were typical for a partly shaded habitat on a clear day at $2 \mathrm{wk}$ and for a cloudy day at the end of a month. Relative humidity at leaf level was high, especially on the final sampling date, and comparable between treatments on both dates. Measured midday air temperatures for both treatments were moderate $\left(20.7^{\circ}-23.3^{\circ} \mathrm{C}\right)$. Rainfall was higher in the final $2 \mathrm{wk}$ of the experiment than in the first $2 \mathrm{wk}: 17.8$ $\mathrm{mm}$ compared to $12.4 \mathrm{~mm}$ (NOAA 1985). Soil moistures were similar between treatments and the differences between dates paralleled rainfall variation.

\section{Plant physiological response}

The differences in the physiological parameters between our treatments suggest that we imposed moderate, but transient, midday water deficit stress by severing rhizomes and peripheral roots (Table 2). Deficits in dawn leaf water potentials were small and similar between treatments on both sampling dates. However, at midday the transient leaf water deficits were moderately high (sensu Hsiao 1973) and greater for the stress treatment than for the control $(P<.05)$. At midday, leaf temperatures and stomatal resistances were similar between treatments on both dates (Table 2). Both of these variables were higher on 1 July than on 18 July, possibly reflecting the lower rainfall in the first 2 wk of the experiment. Higher relative humidity at the end of the experiment (Table 1) may also have contributed. The results thus indicate that severing rhizomes early in the growing season inflicted moderate water deficit stress, and that the extent of response varied with replicate position (Fig. 1) within the local environment (see below, Results: Intrapopulation variation).

\section{Plant chemical response}

Analysis of plant chemical response to the cutting of rhizomes and lateral roots had six main results (Table 3). First, chemical responses overall were not consistent, leading to a nonsignificant, though suggestive, MANOVA model $(P<.12)$.

Second, the amount and quality of nitrogen did not increase with stress overall. We found that total nitro- 
TABLE 1. Physical habitat characteristics during the experiment near stressed (root-cut) and control clones of bittercress (19 June-18 July 1985). $\dagger \neq$

\begin{tabular}{|c|c|c|c|c|c|c|c|c|c|c|}
\hline & \multicolumn{4}{|c|}{ July 1985 (week 2) } & \multicolumn{5}{|c|}{18 July 1985 (week 4) } & \multirow[b]{3}{*}{$P$} \\
\hline & \multicolumn{2}{|c|}{ Stress } & \multicolumn{2}{|c|}{ Control } & \multirow[b]{2}{*}{$P$} & \multicolumn{2}{|c|}{ Stress } & \multicolumn{2}{|c|}{ Control } & \\
\hline & $\bar{X}$ & SE & $\overline{\bar{X}}$ & SE & & $\overline{\bar{X}}$ & SE & $\bar{X}$ & SE & \\
\hline $\operatorname{PAR}\left(\mu \mathrm{mol} \cdot \mathrm{m}^{-2} \cdot \mathrm{s}^{-1}\right)$ & 1076 & 96 & 1124 & 129 & NS & 649 & 136 & 678 & 146 & NS \\
\hline RH $(\%)$ & 32.4 & 2.19 & 34.0 & 3.86 & NS & 45.1 & 5.36 & 45.5 & 6.15 & NS \\
\hline Air temperature $\left({ }^{\circ} \mathrm{C}\right)$ & 23.4 & 0.18 & 22.9 & 0.27 & NS & 20.7 & 1.01 & 21.1 & 0.93 & NS \\
\hline Soil moisture $(\%)$ & 28.7 & 2.52 & 26.9 & 2.89 & NS & 35.6 & 3.55 & 36.0 & 3.37 & NS \\
\hline
\end{tabular}

† Taken at upper leaf surface near midday $(1100-1400 \mathrm{~h})$ or near experimental plants.

$\ddagger N=5$ paired replicates per treatment; two-way ANOVA for paired comparison by date and treatment, $F$ test $(1,1,4 \mathrm{df})$; $\mathrm{NS}=P>.20$.

gen, free amino nitrogen, and total amino acid concentrations were similar between treatments, all $P>$ .20). Also, the ninhydrin estimates of beta-amino nitrogen concentrations, which include primarily proline and hydroxyproline, appeared high (64-68\%) but comparable between treatments $(P>.20)$. HPLC estimates of individual amino acid concentrations both substantiated the absence of response in proline, an amino acid that often increases with stress (Mattson and Haack $1987 a, b)$, and showed a significant difference only in isoleucine (Table 3).

Third, nitrate-nitrogen concentrations increased significantly in the stress treatment $(P<.05)$. This result supports the interpretation that our treatment induced moderate stress. Reduction in nitrate reductase, and thus accumulation of nitrate, is often an initial response to stress (Hsiao 1973, Mattson and Haack 1987a, b).

Fourth, the sugar content of leaf tissues doubled. Total concentration of nonstructural carbohydrates, which includes all simple sugars and sugar alcohols but excludes starch and cellulose, was significantly higher for stressed plants than for control plants $(P<.003)$. Hydrolysis of starch usually increases with stress (Gates 1964, Mattson and Haack 1987a, $b$ ).

Fifth, leaf water content was similar between treatments. Thus, any insect response could not be explained by treatment-induced differences in the availability of water in the foliage.

Sixth, the concentrations of characteristic secondary compounds, the isothiocyanate-yielding glucosinolates, appeared somewhat higher in stressed plants than in control plants, but the difference was not quite significant statistically $(P<.10$, Table 3$)$. Absolute levels of glucosinolate observed were relatively low $(\bar{X}=1.78$ $\mathrm{mg} / \mathrm{g}$ ). Since average glucosinolate concentrations normally decline throughout the growing season (Rodman and Louda 1984, 1985), the difference that we observed suggests that the usual decline was retarded by the stress treatment.

In sum, the chemical differences associated with the imposition of root-cutting stress in early season, when total leaf nitrogen concentrations were relatively high $(>3.6 \%)$, were increases in: isoleucine (133\%), sugars $(105 \%)$, nitrate nitrogen (20\%), and possibly glucosinolates $(25 \%)$. As a consequence of the changes above, one ratio of nutrients-to-allelochemicals increased: the ratios actually declined: total nitrogen-to-glucosinolates $(22 \%)$ and total amino acids-to-glucosinolates $(32 \%$, Table 3$)$.

\section{Herbivore response}

Insect damage increased significantly on plants in the stress treatment (Fig. 2). The increase in leaf area damaged (LAD) on plants in the stress treatment was exponential (Fig. 2A, B). The time lag in the development of damage could reflect the lag between oviposition and accumulation of feeding damage, the relative rates of leaf expansion and consumption, or the greater differences in transient water deficits later in the experiment. The MANOVA models explained a significant portion of the variation in damage on all

TABLE 2. Physiological response of bittercress to root-cutting vs. the control treatment (1985) at the Main Site, Gothic, Colorado. $\dagger$

\begin{tabular}{|c|c|c|c|c|c|c|c|c|}
\hline & \multicolumn{4}{|c|}{1 July 1985 (week 2) } & \multicolumn{4}{|c|}{18 July 1985 (week 4) } \\
\hline & \multicolumn{2}{|c|}{ Stress } & \multicolumn{2}{|c|}{ Control } & \multicolumn{2}{|c|}{ Stress } & \multicolumn{2}{|c|}{ Control } \\
\hline & $\bar{X}$ & SE & $\bar{X}$ & SE & $\bar{X}$ & SE & $\bar{X}$ & SE \\
\hline Dawn leaf water potential deficit (MPa) & -0.27 & 0.34 & -0.29 & 0.33 & -0.30 & 0.29 & -0.25 & 0.53 \\
\hline Midday leaf water potential deficit (MPa) & -1.53 & 0.81 & -1.39 & 0.72 & -1.16 & 0.11 & -0.89 & 0.12 \\
\hline Stomatal resistance $(\mathrm{s} / \mathrm{cm})$ & 9.62 & 0.86 & 9.20 & 0.95 & 5.38 & 0.60 & 5.68 & 0.66 \\
\hline Leaf temperature $\left({ }^{\circ} \mathrm{C}\right)$ & 22.5 & 0.21 & 22.2 & 0.41 & 19.8 & 0.94 & 20.2 & 0.90 \\
\hline
\end{tabular}

$\dagger N=5$ replicates per treatment; two-way mixed-model ANOVA of date and treatment, $F_{(1,1,4)}$, NS $=P>.20$. 
TABLE 3. Chemical differences and insect damage 1 mo (18 July) after root-cutting treatment on bittercress early in the growing season (19 June 1985). $†$

\begin{tabular}{|c|c|c|c|c|c|c|}
\hline \multirow[b]{2}{*}{ Variables } & \multicolumn{2}{|c|}{ Stress } & \multicolumn{2}{|c|}{ Control } & \multirow[b]{2}{*}{$F$} & \multirow[b]{2}{*}{$P$} \\
\hline & $\bar{X}$ & SE & $\bar{X}$ & SE & & \\
\hline \multicolumn{7}{|c|}{ Primary compounds } \\
\hline Total nitrogen (TN, \%) & 3.65 & 0.10 & 3.9 & 0.28 & 0.56 & NS \\
\hline Free amino nitrogen $(\mathrm{mg} / \mathrm{g})$ & 18.5 & 2.45 & 20.4 & 2.31 & 0.28 & NS \\
\hline Beta-amino N (\%) & 64.7 & 2.46 & 67.9 & 3.65 & 0.58 & NS \\
\hline Total amino acids $\ddagger$ (TAA, mg/g) & 2.94 & 0.82 & 2.75 & 0.62 & 0.01 & NS \\
\hline Isoleucine $(\mathrm{mg} / \mathrm{g})$ & 0.07 & 0.01 & 0.03 & 0.01 & 11.25 & 0.01 \\
\hline Proline $(\mathrm{mg} / \mathrm{g})$ & 0.14 & 0.04 & 0.12 & 0.09 & 0.35 & NS \\
\hline Nitrate nitrogen $(\mu \mathrm{g} / \mathrm{g})$ & 1260 & 69.6 & 1050 & 52.44 & 5.80 & 0.043 \\
\hline Soluble carbohydrates (TNC, \%) & 12.9 & 1.69 & 6.3 & 0.45 & 16.96 & 0.003 \\
\hline Leaf water content $(\%)$ & 84.9 & 1.02 & 86.4 & 1.18 & 1.00 & NS \\
\hline \multicolumn{7}{|c|}{ Secondary compounds and nutrient-allelochemical ratios } \\
\hline Glucosinolates (IYG, mg/g) & 1.97 & 0.18 & 1.58 & 0.10 & 3.48 & 0.099 \\
\hline TN/IYG & 1.91 & 0.17 & 2.46 & 0.12 & 6.92 & 0.03 \\
\hline TAA/IYG & 1.54 & 0.45 & 1.70 & 0.35 & 0.08 & NS \\
\hline TNC/IYG & 6.88 & 1.21 & 4.14 & 0.53 & 4.31 & 0.071 \\
\hline \multicolumn{7}{|c|}{ Associated insect damage } \\
\hline Leaf area damaged $\left(\mathrm{mm}^{2} / \mathrm{leaf}\right)$ & 89.7 & 11.29 & 53.0 & 5.92 & 47.01 & 0.001 \\
\hline Leaf area mined $\left(\mathrm{mm}^{2} / \mathrm{leaf}\right)$ & 71.8 & 11.44 & 31.6 & 5.55 & 29.97 & 0.001 \\
\hline Pitting (\%) & 29.3 & 4.55 & 30.3 & 4.82 & 1.06 & NS \\
\hline
\end{tabular}

three dates, using Wilk's Criterion and Hotelling-Lawley Trace tests (Table 4; Wilkinson 1986).

Initially (19 June 1985), the herbivore loads were low and very similar for both treatments (Fig. 2A, B, $C)$, except that more leaves of the controls had been pitted by the sap-feeding psyllids (Fig. 2D, Table 4). Even this early in the season, replicates around the stand (Fig. 1) differed significantly in all estimates of herbivore load except in pitting (Table 4). Replicate differences typically persisted, and led to an interaction between replicate and treatment in determining level of damage (Table 4).

Two weeks after cutting rhizomes ( 1 July), two differences between treatments occurred. The amount of pitting increased more on stressed plants than on controls (38.2 vs. $11.8 \%, P<.05$; Fig. 2D). The cause cannot be inferred; it may have been a response to either the initial difference in herbivore load between the treatments or to the stress treatment. Second, the

TABle 2. Continued.

\begin{tabular}{|c|c|c|c|c|c|}
\hline \multicolumn{2}{|c|}{ Date } & \multicolumn{2}{|c|}{ Stress } & \multicolumn{2}{|c|}{ Interaction } \\
\hline$F$ & $P$ & $F$ & $P$ & $F$ & $P$ \\
\hline 0.03 & NS & 0.15 & NS & 0.91 & NS \\
\hline 20.75 & 0.001 & 4.50 & 0.05 & 0.42 & NS \\
\hline 24.64 & 0.001 & 0.01 & NS & 0.22 & NS \\
\hline 11.54 & 0.004 & 0.01 & NS & 0.32 & NS \\
\hline
\end{tabular}

proportion of leaves with mines increased on control plants $(P<.02$; Fig. $2 \mathrm{~F}$, Table 4$)$, suggesting a difference in the distribution of either egg deposition or early instar success between the two treatments. No differences in the total amount of leaf area chewed (Fig. 2B) or mined (Fig. 2C) were evident at 2 wk (Table 4).

One month after the treatment, significant variation in loss among the replicates persisted (Table 4). Four of the five variables used to estimate insect response to stressed plants were significantly higher for plants in the treatment with severed peripheral roots (Table 4). The one variable that was not was the proportion of leaves pitted (Fig. 2E), probably as a result of low oviposition rates by psyllids late in the season (J. R. Fleming and S. M. Louda, unpublished data). Overall, the results show that ramets in the stress treatment were generally and significantly more vulnerable to damage by chewing insect herbivores, particularly by the leaf miners, than were ramets in the control treatment. The opposite appeared true for sucking insects.

At the end of the experiment the area damaged by leaf miners was significantly higher on plants with severed roots (Fig. 2C, Table 4). Also, leaf-mining contributed a significantly higher proportion of total leaf area lost in the stress treatment than in the control treatment: 80.4 vs. $59.2 \%$ (paired $t$ test, $P<.05$, Fig. $2 \mathrm{~A}, \mathrm{C})$. The higher cumulative amount of leaf area mined in the stress treatment after 1 mo reflected at least four factors: (1) $42 \%$ more mines per leaf (Fig. $\left.3 \mathrm{~A}, F_{(1,1,4)}=4.27, P<.03\right),(2) 127 \%$ greater area mined per leaf (Fig. 3B), (3) $45 \%$ higher proportion of leaves mined (Fig. 2F), and (4) 59\% larger mines (Fig. 3C). 
A

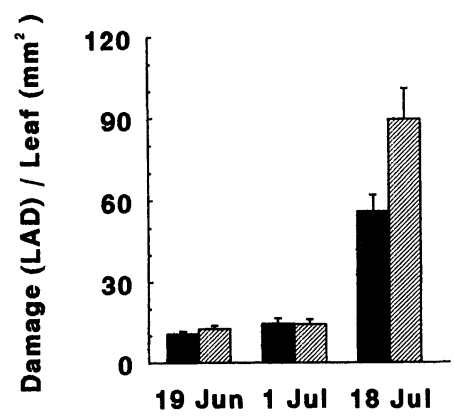

D

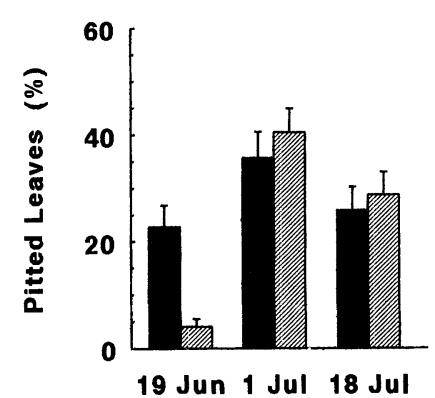

B

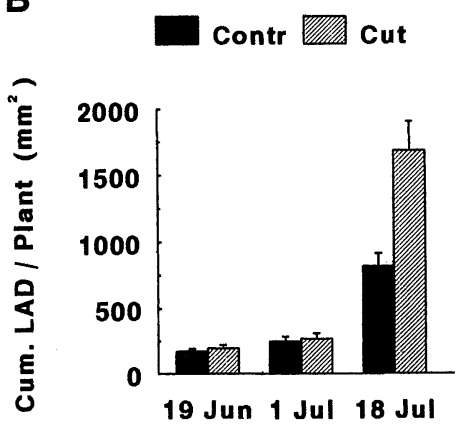

$\mathbf{E}$

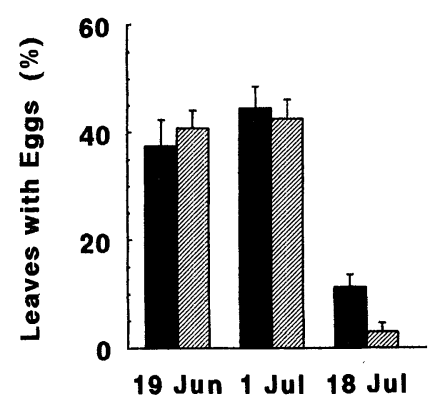

C

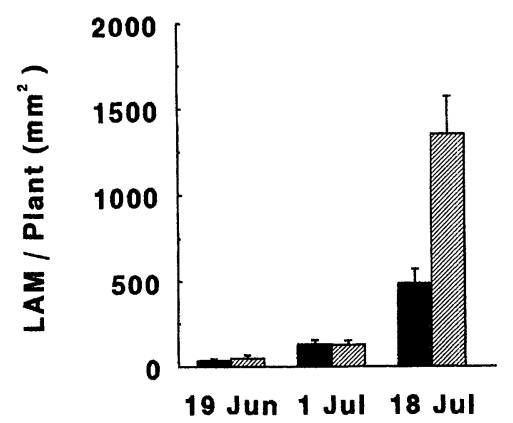

$\mathbf{F}$

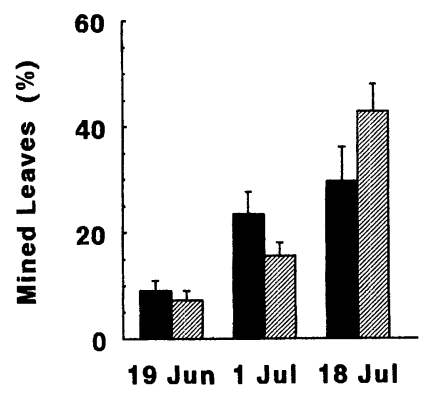

FIG. 2. Insect and damage response to the stress treatment imposed on 19 June 1985 by severing rhizomes 4-6 cm from the root crown of bittercress, Cardamine cordifolia, compared to the paired control treatment: (A) total leaf area damaged (LAD) per leaf, (B) average cumulative, total LAD for all leaves on a ramet, (C) leaf area mined (LAM) per ramet, (D) proportion of leaves pitted by psyllids per ramet (\%), (E) proportion of leaves with psyllid eggs per ramet (\%), and (F) proportion of leaves with leaf mines per ramet (\%). Significant differences between treatments were identified using two-way ANOVA of the significant MANOVA model (Table 4). Data are means and 1SD.

TABLE 4. Multivariate and univariate analyses of variance in insect damage per bittercress ramet in response to root-cutting stress in June 1985.†

\begin{tabular}{|c|c|c|c|c|c|c|c|}
\hline \multirow[b]{2}{*}{ Variables $\ddagger$} & \multicolumn{2}{|c|}{ Treatment } & \multicolumn{2}{|c|}{ Replicate } & \multicolumn{2}{|c|}{ Interaction } & \multirow[b]{2}{*}{$R^{2}$} \\
\hline & $F$ & $P$ & $F$ & $P$ & $F$ & $P$ & \\
\hline 19 June MANOVA (df 5,40 ) & 4.21 & $0.004^{*}$ & & & & & \\
\hline Cumulative LAD/ramet & 1.38 & NS & 17.38 & $0.001^{*}$ & 2.92 & 0.033 & .674 \\
\hline Cumulative LAM/ramet & 0.12 & NS & 24.87 & $0.001^{*}$ & 4.66 & $0.003^{*}$ & .747 \\
\hline Pitting (\% lvs/ramet) & 22.39 & $0.001^{*}$ & 0.76 & NS & 2.99 & $0.030^{*}$ & .483 \\
\hline Eggs (\% lvs/ramet) & 1.13 & NS & 6.39 & $0.001^{*}$ & 1.25 & NS & .442 \\
\hline Mining (\% lvs/ramet) & 0.59 & NS & 12.05 & $0.001^{*}$ & 3.47 & $0.020^{*}$ & .610 \\
\hline 1 July MANOVA (df 5,39) & 2.78 & 0.04 & & & & & \\
\hline Cumulative LAD/ramet & 0.01 & NS & 16.02 & $0.001 *$ & 8.73 & $0.001^{*}$ & .712 \\
\hline Cumulative LAM/ramet & 0.68 & NS & 85.33 & $0.001 *$ & 4.19 & $0.006^{*}$ & .900 \\
\hline Pitting (\%) & 1.03 & NS & 9.47 & $0.001^{*}$ & 4.76 & $0.003^{*}$ & .592 \\
\hline Eggs $(\%)$ & 0.32 & NS & 4.48 & $0.004 *$ & 1.31 & NS & .370 \\
\hline Mining (\%) & 6.55 & $0.014^{*}$ & 36.82 & $0.001^{*}$ & 2.03 & 0.109 & .802 \\
\hline 18 July MANOVA (df 5,40 ) & 4.53 & $0.003^{*}$ & & & & & \\
\hline Cumulative LAD/ramet & 43.99 & $0.001^{*}$ & 38.65 & $0.001^{*}$ & 3.80 & $0.010^{*}$ & .842 \\
\hline Cumulative LAM/ramet & 23.14 & $0.001^{*}$ & 33.84 & $0.001 *$ & 2.18 & 0.089 & .807 \\
\hline Pitting (\%) & 0.07 & NS & 2.55 & 0.054 & 5.65 & $0.001^{*}$ & .451 \\
\hline Eggs $(\%)$ & 12.66 & $0.001 *$ & 2.85 & 0.036 & 0.94 & NS & .410 \\
\hline Mining (\%) & 9.48 & $0.004^{*}$ & 50.62 & $0.001^{*}$ & 11.02 & $0.001^{*}$ & .865 \\
\hline
\end{tabular}


A

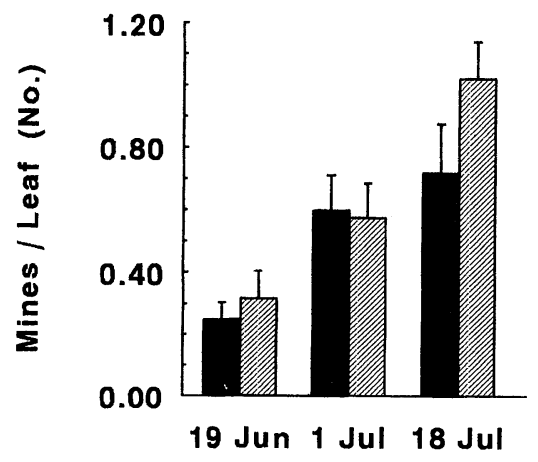

C

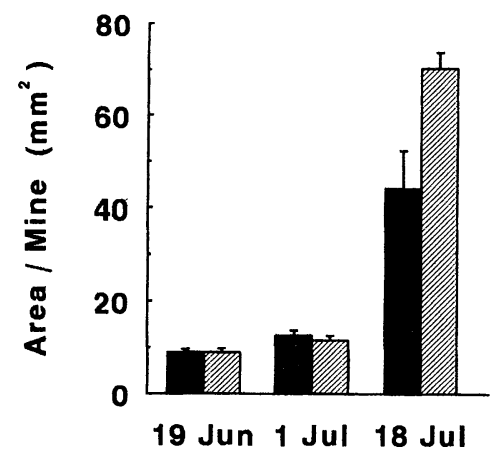

B

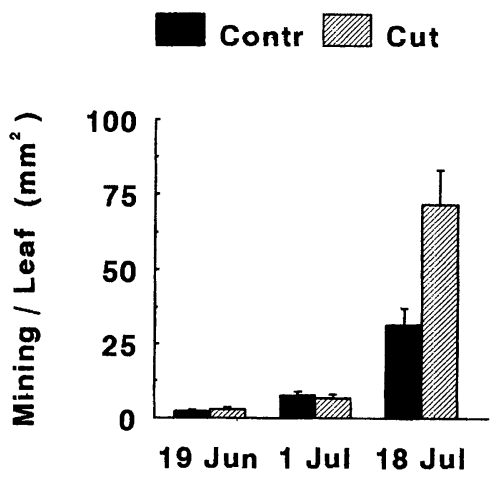

D

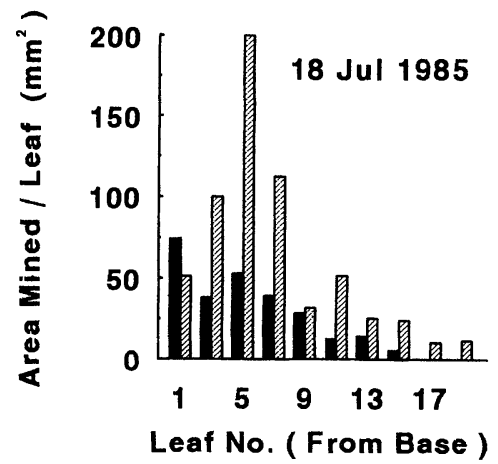

Fig. 3. Parameters of leaf mining in stress and control treatments on bittercress (Cardamine cordifolia), stress imposed in early season (1985): (A) number of mines per leaf, (B) average area mined per leaf, (C) estimated area per mine [leaf area mined]/[number of mines] on a per leaf basis, and (D) area mined per leaf in relation to leaf position from base to apex of ramet. Data are means and 1 SD.

None of these four responses observed were caused by initial differences (Table 4). Finally, both the median and mode of the frequency distribution of leaf mining (LAM) shifted to the right, to younger leaves higher on the ramet, in the stress treatment (Fig. 3D).

\section{Plant growth and reproductive response}

Plant growth and reproductive responses to stress and the associated increase in herbivory were complicated. The MANOVA model included six variables: ramet height, number of basal leaves, number of cauline leaves, average length of cauline leaves, cumulative leaf mortality, and reproductive potential per ramet. Using Wilk's Criterion and the Hotelling-Lawley Trace tests, this model explained a significant portion of the observed variation, both initially and at the midpoint of the experiment, but not at the end of the experiment (Table 5).

Initially, plants in control clones were somewhat more advanced phenologically (Fig. 4). Control ramets were taller (Fig. 4A, $P<.001$ ), with fewer basal leaves (Fig. 4B, $P<.003$ ), and more reproductive investment in flower buds $(P<.001)$. Replicates also differed among each other in ramet height, number of leaves, and flower buds present (Table 5).

Two weeks after cutting rhizomes, the initial differences between treatments in stem height (Fig. 4A) and in leaf length (Fig. 4E) had disappeared. The difference in the number of basal leaves reversed (Fig. 4B) and was not significant. And, a marginally significant increase in the number of cauline leaves (Table 5) occurred for the stressed plants (Fig. 4D). Cutting roots did not accelerate leaf mortality over the first 2 -wk period (Fig. 4F). Reproductive potential, i.e., flower buds and flowers on this date, continued to be higher on control plants than on stressed ones (Table 5).

Four weeks after treatment, no significant differences remained between treatments in height (Fig. 4A), number of basal leaves (Fig. 4B), or length of cauline leaves (Fig. 4E). The earlier trend toward a greater number of cauline leaves on ramets in the stress treatment became larger (Fig. 4D) and significant (Table 5). And, in spite of greater leaf mortality (Fig. 4F) of the more heavily damaged leaves on stressed plants (Fig. 2A), 
TABLE 5. Multivariate and two-way analyses of variance of growth and seed production by bittercress in response to stress imposed by severing rhizomes in early $1985 . \dagger$

\begin{tabular}{|c|c|c|c|c|c|c|c|}
\hline \multirow[b]{2}{*}{ Variables } & \multicolumn{2}{|c|}{ Treatment } & \multicolumn{2}{|c|}{ Replicate } & \multicolumn{2}{|c|}{ Interaction } & \multirow[b]{2}{*}{$R^{2}$} \\
\hline & $F$ & $P$ & $F$ & $P$ & $F$ & $P$ & \\
\hline 19 June MANOVA (df 6,39) & 6.52 & $0.001^{*}$ & & & & & \\
\hline Ramet height (cm) & 18.86 & $0.001^{*}$ & 10.75 & $0.001^{*}$ & 4.00 & 0.010 & .661 \\
\hline Basal leaves (no.) & 9.76 & $0.003^{*}$ & 3.49 & $0.020^{*}$ & 2.08 & 0.110 & .445 \\
\hline Cauline leaves (no.) & 0.00 & NS & 6.86 & $0.001 *$ & 1.15 & NS & .445 \\
\hline Leaf length (mm) & 2.43 & 0.130 & 0.97 & NS & 0.49 & NS & .172 \\
\hline Leaf mortality (no.) & 3.19 & 0.080 & 1.67 & NS & 0.77 & NS & .245 \\
\hline Reproductive potential & 14.75 & $0.001^{*}$ & 5.65 & $0.002^{*}$ & 1.28 & NS & .515 \\
\hline 1 July MANOVA (df 6,39) & 3.81 & $0.005^{*}$ & & & & & \\
\hline Ramet height $(\mathrm{cm})$ & 0.20 & NS & 2.76 & 0.041 & 2.18 & 0.089 & .333 \\
\hline Basal leaves (no.) & 1.84 & NS & 6.46 & $0.001^{*}$ & 2.10 & 0.099 & .474 \\
\hline Cauline leaves (no.) & 3.54 & 0.067 & 0.67 & NS & 1.24 & NS & .218 \\
\hline Leaf length (mm) & 0.18 & NS & 1.78 & 0.151 & 0.28 & NS & .174 \\
\hline Leaf mortality (no.) & 1.06 & NS & 1.14 & NS & 3.64 & $0.013^{*}$ & .336 \\
\hline Reproductive potential & 10.65 & $0.002 *$ & 0.08 & NS & 0.43 & NS & .241 \\
\hline 18 July MANOVA (df 6,39) & 2.69 & 0.100 & & & & & \\
\hline Ramet height (cm) & 1.91 & 0.174 & 4.46 & $0.005^{*}$ & 10.75 & $0.001^{*}$ & .611 \\
\hline Basal leaves (no.) & 0.03 & NS & 1.20 & NS & 0.60 & NS & .153 \\
\hline Cauline leaves (no.) & 8.85 & $0.004^{*}$ & 0.23 & NS & 0.74 & NS & .241 \\
\hline Leaf length $(\mathrm{mm})$ & 0.44 & NS & 2.20 & 0.086 & 0.51 & NS & .220 \\
\hline Leaf mortality (no.) & 3.79 & 0.059 & 14.90 & $0.001^{*}$ & 6.44 & $0.001^{*}$ & .690 \\
\hline Reproductive potential & 1.80 & 0.188 & 3.11 & $0.026^{*}$ & 7.81 & $0.001^{*}$ & .532 \\
\hline Fruit production & 1.55 & NS & 5.19 & $0.002^{*}$ & 14.72 & $0.001^{*}$ & .670 \\
\hline
\end{tabular}

$*=$ significant at $P \leq .030$ using Bonferroni criterion for multiple comparisons; $\mathrm{NS}=P>.200$.

$\dagger$ Test of MANOVA model for each date presented first; then, two-way ANOVA of treatment and replicate pair $(\mathrm{df}=1,1,4)$ for each variable.

A

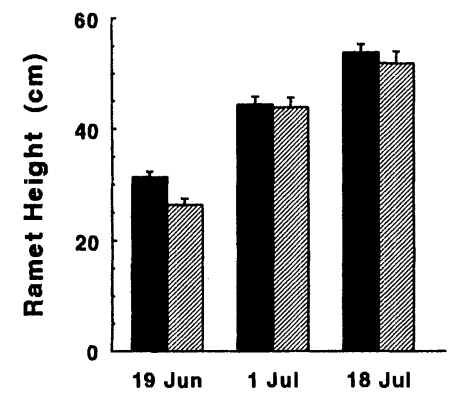

D

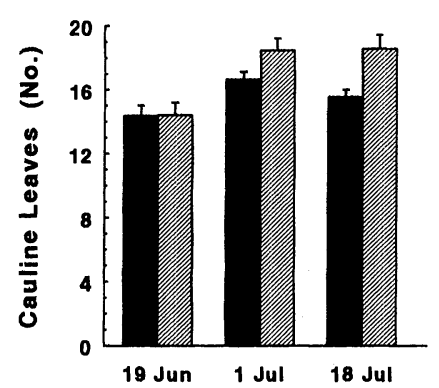

B

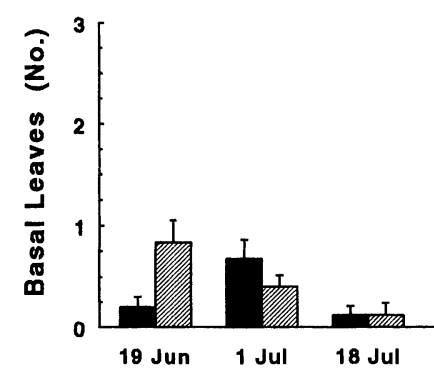

$\mathbf{E}$

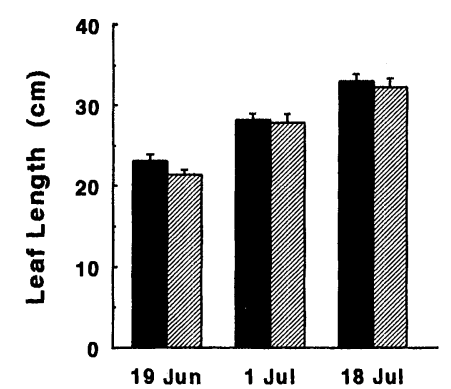

C

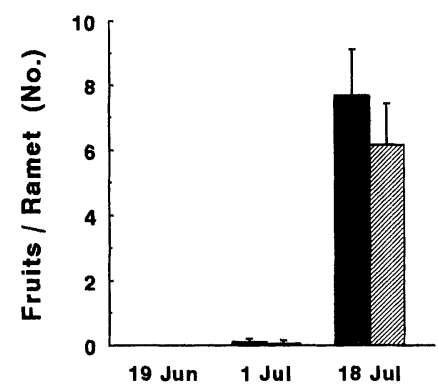

$\mathbf{F}$

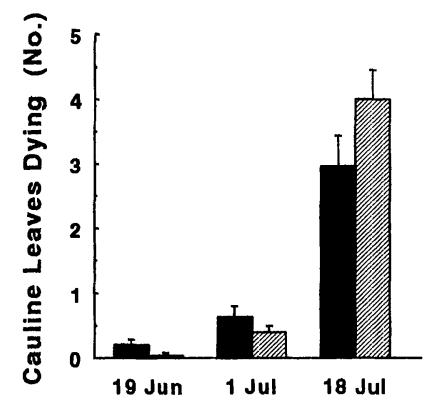

Fig. 4. Plant response to stress treatment imposed by severing rhizomes $4-6 \mathrm{~cm}$ from the root crown of bittercress, Cardamine cordifolia, compared to the controls: (A) ramet height $(\mathrm{cm}),(\mathrm{B})$ number of basal leaves, (C) number of siliques (fruits) per ramet, (D) number of cauline leaves per ramet, (E) average leaf length of the cauline leaves on a ramet, and (F) average number of yellow + dead + missing leaves on a ramet. Significant differences between treatments were identified using two-way ANOVA. Data are means and 1SD. 
the net effect was a $16 \%$ increase in the number of living cauline leaves by 18 July (Fig. 4F). However, the plants in the stress treatment tended to form fewer fruits by 18 July (Fig. 4C). The observed increase in leaf mortality and decreasing trend in fruit production were consistent with findings from previous studies of herbivory on bittercress (Louda 1984, 1986).

\section{Intrapopulation variation in plant and herbivore response}

Herbivory increased on stressed plants; however, the magnitude of most plant and herbivore responses varied significantly among the replicates (Tables 4 and 5). Replicates were distributed around the $400 \mathrm{~m}^{2}$ stand (Fig. 1). Initially, the replicates differed significantly in early season damage (Table 4); replicate $V$ was most damaged and replicate III was least damaged $(P<.05)$. The average level of herbivory by chewing, mining, and sap-feeding insect guilds continued to vary significantly among replicates throughout the experiment (Table 4). The least variation among replicates occurred in frequency of pitting by psyllids and of psyllid eggs (Table 4); the psyllids were the predominant sapfeeding insects. However, even the variation in psyllid damage among replicates was statistically significant at the midpoint of the experiment (Table 4).

By the end of the experiment, the replicates' stressed clones (Fig. 1) consistently ranked V, IV $>>$ I $>$ II $>>>$ III for chewing and mining damage; and, control clones ranked V $>>$ II, IV $>$ I $>>>$ III $(P<$ $.05)$. Thus, the extremes (V high, III low) were established early in the season and persisted. Replicate V was consistently the most damaged and replicate III was the least damaged, with or without the experimental imposition of stress. However, stress altered the relative ranking among the remaining replicates, damage increased on replicates IV and I relative to replicate II.

Early in the season, the level of chewing damage correlated only with ramet height $(P<.05)$. This variation persisted, and interacted with treatment (Table 4), in determining the magnitude of observed herbivore response to stressed plants. Plant growth and reproduction also varied significantly among replicates in three, and marginally in a fourth, of the six factors measured to record plant response to stress and herbivory (Table 5). Initially these included plant height, number of basal and cauline leaves, and number of flower buds (Table 5). This variation among replicates persisted throughout the season and, for three of the six variables, interacted with treatment to affect the magnitude of plant response to stress and herbivory.

\section{DisCUSSION}

\section{Stress in plant-insect herbivore interactions}

Insect herbivory increased when we imposed moderate stress on bittercress relatively early in the growing season. The treatment effect was large and clearcut (Figs. 2 and 3, Table 4). And, our test shows that three of the four main assumptions underlying the stress hypothesis for variation in insect herbivory held.

First, the imposition of stress should alter plant physiological status, and it did, by increasing midday leaf water deficits (Table 2) and nitrate-nitrogen concentrations (Table 3).

Second, stress should induce chemical changes that improve leaf quality for adapted insects and it did, by causing higher levels of isoleucine and soluble carbohydrate, and possibly glucosinolates (Table 3 ). Increases in an amino acid and in sugars should increase palatability to insects generally (Slansky and Rodriguez 1987). Furthermore, if absolute levels of the characteristic compounds, the mustard-oil precursors or glucosinolates, are relatively low, as here, then an increase in their concentration could be expected to increase the use of crucifers by crucifer-feeding insects (Thorsteinson 1960, Chew 1988, Louda and Mole 1992).

Third, insects should respond to changes in plant quality of differentially stressed plants, and chewing and mining insects did (Figs. 2 and 3; Table 4). The increase in damage to foliage with stress is consistent with previous studies of bittercress (Louda and Rodman 1983a, $b$, Louda 1986, 1988, Collinge and Louda $1988 a, b)$ and of many other plants (e.g., White 1969 , $1974,1976,1978$, Lewis 1979, 1984, Bernays and Lewis 1986, Mattson and Haack 1987a, b). For example, moderate stress increases herbivory on: herbaceous native species, such as annual sunflower Helianthus annuus (Lewis 1979, 1984), Rocky Mountain bee plant Cleome serrulata (Louda et al. 1987b), and some of the forbs in montane meadows (Louda et al. 1987a, $c$; on crop plants, such as tomatoes and soybeans (Hughes et al. 1982a, b, Hughes 1988); and, on a variety of forest trees (see Mattson and Haack 1987a, $b$, Heinrichs 1988). Two main exceptions are common. Sapfeeding insects, such as psyllids (Fig. 2D, E) and stem gallers (e.g., Waring and Price 1988) seem to respond to nitrogen availability rather than to stress-altered characters, such as sugars.

Finally, fourth, if the hypothesis is correct, then increased losses should translate into decreased relative fitness for stressed plants. Although a previous study showed a significant impact of herbivory on fitness parameters of bittercress (Louda 1984), the negative trends observed here, on height (Fig. 4A), leaf survival (Fig. 4F), and number of fruits (Fig. 4C) of the moderately stressed plants, were not statistically significant (Table 5). Ending the experiment early, in order to do chemical tests on still vigorous plants, most likely contributed to this result.

In sum, stress contributed significantly to the pattern of herbivory caused by the adapted insects to a native forb within its typical habitat. The level of stress imposed was moderate, as estimated by small, but significant increases in transient leaf water deficits. These 
results are consistent with the hypothesis that responses by foliage-feeding arthropods to stressed plants are not linear; damage appears to increase and then decline as the intensity of stress intensifies (Louda 1986, 1988, Louda et al. 1987c, Mattson and Haack 1987a, $b$, English-Loeb 1989). Thus, our results appear to highlight the importance of moderate, rather than severe, intensities of stress in the facilitation of herbivory by chewing insects on foliage.

\section{Plant compensation for stress and herbivory}

Herbivory following moderate stress prevented full compensation for early season reproductive differences (Table 5), in spite of increases in cauline leaves (Fig. 4D). Fruit production was lower on stressed plants (Fig. 4C) in at least some replicates (Table 5). One hypothesis to explain the increase in cauline leaves is based on the way in which we imposed stress. Carbohydrates are normally shunted to roots and rhizomes for vegetative reproduction and clonal integration (e.g., Hartnett and Bazzaz 1983). With root-cutting, carbohydrates may have been reallocated to aboveground growth.

\section{Differences in herbivore guild responses}

Leaf mining damage was a significant part of the total damage to leaves (Fig. 2B, C). Mines were more abundant, larger, and distributed onto more leaves on stressed plants (Fig. 3). One month after roots were cut more leaves had mines (Fig. 2F), more mines were initiated per leaf (Fig. 3A), and the median amount of mining damage per leaf increased (Fig. 3D). The observation that mines were both more abundant and larger on stressed plants is consistent with other experiments on this system (Louda 1986, 1988, Collinge and Louda $1988 a, b$ ). Leaf miners choose leaves that improve larval survival and growth (Bultman and Faeth 1986, Faeth 1988).

Alternately, however, the damage and occurrence of sap-sucking herbivores was not clearly enhanced by stressing host plants (Fig. 2). During the first half of the experiment psyllid damage (Fig. 2D), and the frequency of psyllid eggs (Fig. 2E), increased more on ramets in the stress treatment than on those in the controls (Fig. 2D). Few eggs were observed in either treatment in the second half of the experiment. These results suggest the psyllids may have responded to plants in the stress treatment during the oviposition phase of their life cycle; sap-feeding insects may have favored stressed plants, or sap-feeding insects may have preferentially used plants with lower frequencies of previous use by chewing insects. We have no data with which to distinguish between these alternatives.

By the end of the month, sap-feeding insects did not show any increased use of stressed plants (Fig. 2D). The lack of response should be expected. Performance of sap-feeding insects is usually correlated with available nitrogen (e.g., Wearing and van Emden 1967, van
Emden and Bashford 1968, 1971, White 1969-1984, Wearing 1972a, $b$, McNeill 1973, Miles et al. 1982a), and we did not find major differences in total or available nitrogen (Table 3). In a previous experiment, flooding of bittercress increased psyllid occurrence on the stressed plants (Louda 1986). These results would be consistent with our present data if flooding increased nitrogen availability.

\section{Nutrient and allelochemic concentrations}

Nitrogen and secondary compounds are generally thought to mediate insect use of their host plants. Herbivore load on bittercress was not related to differences in plant nitrogen. Perhaps this result should have been expected since total nitrogen concentrations in bittercress were relatively high overall (3.6-3.9\%, Table 3 ). Among the primary nutrients, variation in carbohydrate concentrations is more likely to explain differences in use of bittercress by adapted insects (Table 3; Collinge and Louda 1988b).

Glucosinolate concentrations in our experiment were relatively low, but averaged $25 \%$ higher in stressed plants (Table 3). Elevated concentrations would be consistent with observations of increased glucosinolates under conditions that stress plants (Neil and Bible 1972, Louda and Rodman 1983a, $b$, Gershenzon 1984, Mattson and Haack 1987a). However, the direct relationship between stress and glucosinolates still requires testing. In this system, variation in glucosinolate concentrations in bittercress is large (Louda and Rodman 1983a, b, Rodman and Louda 1984, 1985) and cannot explain differences in herbivory between adjacent habitats (Louda and Rodman 1983a, $b$; S. M. Louda, unpublished manuscript). However, glucosinolates appear to play a role in the variation in bittercress resistance to herbivory within its usual habitat (Louda and Rodman 1983a, $b$, Louda 1988).

In addition, we examined ratios of primary-to-secondary compound concentrations. We expected to find plants with increased nutrient-to-defensive compound ratios to be less resistant to insect herbivory (Janzen 1974, Coley et al. 1985, Bazzaz et al. 1987). We did not find this to be the case for nitrogen. Although herbivory increased, none of the nitrogen-to-glucosinolate concentration ratios increased with stress (Table 3). However, both herbivory and the soluble carbohydrate-to-glucosinolate ratio increased for stressed plants (Table 3). We conclude that when nitrogen content is high and similar among co-occurring plants, as in this system, other differences such as sugar content will mediate herbivory by adapted insects and its impact on plant performance.

\section{Crucifer use by insects: conflicting results}

Our results are consistent with most observations on stress in the resistance of herbaceous plants to insect herbivory, especially crucifers. For example, Josefsson (1970) found that insect damage decreased establish- 
ment and growth of Brassica napus when nutrients or soil moisture were limited. Van Emden and Bashford (1968, 1971), Wearing $(1972 a, b)$, and Miles et al. (1982a) recorded improved growth by aphids on waterstressed crucifers. Hicks and Tahvanainen (1974) found that increased herbivory led to higher mortality of Dentaria diphylla transplanted from forest to open field. And, Wolfson $(1980,1982)$ found that oviposition and growth of Pieris rapae increased on Brassica nigra on plants with limited water.

Our results conflict, however, with two studies of oviposition and larval growth of the cosmopolitan, cabbage white butterfly, Pieris rapae. We found differences in insect use and damage by chewing insects without finding differences in total nitrogen, free amino nitrogen, or total amino acid concentrations (Table 3). In contrast, Myers (1985) found that oviposition by the cabbage white butterfly was higher on fertilized cabbage and unrelated to watering regime. And Miles et al. (1982b) found that feeding and growth of P. rapae larvae were not related to leaf water status of Brassica oleracea, but positively correlated with glucosinolate concentrations.

Our hypothesis to explain the differences observed among studies reflects the fact that the plants used by Myers (1985) and Miles et al. (1982b) were grown in pots in the greenhouse, whereas ours were in the field. Use of greenhouse-grown plants involves at least four potentially confounding assumptions. These are that (1) leaf quality of greenhouse and naturally occurring plants is similar, (2) plants in pots are not stressed, (3) cultivation methods cause no modification of the relationship among parameters influencing insect choice and feeding, and (4) interactions of a cosmopolitan insect with a cultivar are similar to interactions of indigenous insects with native plants.

These assumptions appear questionable. First, plant growth is plastic and related to growing conditions (e.g., Nobel 1983). Plants grown under greenhouse conditions usually differ substantially from plants grown outside, including traits that influence insects (see Slansky and Rodriguez 1987), such as leaf size, thickness, toughness, and water and nitrogen content. Choice among greenhouse-grown plants and larval rearing on them may reflect only choice or response among very similar, tender, nutritious leaves of greenhouse-grown plants. Second, all plants in pots may be moderately stressed, at least comparable to the levels measured in the field in our study. Third, nitrogen and sugars may interact to determine crucifer attractiveness to adapted insects. Levels of nitrogen in bittercress are relatively high, compared to usual levels in brassicas. Perhaps when leaf nitrogen is low or variable, the nitrogen status of leaves forms the primary criterion of oviposition and feeding, as Myers (1985) and Miles et al. (1982b) found, whereas when leaf nitrogen is high, as in bittercress, the increases in the concentration of leaf sugars associated with moderate stress may be more im- portant, as we found. Finally, fourth, our results suggest that a cosmopolitan pest species on a cultivar does not represent a general model for the interaction of indigenous insects with native crucifers, such as bittercress.

\section{Intraspecific variation in stress and herbivore response}

The existence of early, large, and persistent differences in damage among the replicates (Tables 4 and 5) was a striking, unexpected but important, outcome of this study. Experimental stress induced increased herbivory generally (Fig. 2). However, the replicates varied significantly in the overall amount of damage that they experienced (Table 4). Replicate V was consistently the most damaged, and replicate III the least, with or without the experimental imposition of stress. These differences were established early and persisted. Stress altered the relative ranking among replicates with intermediate levels of damage, shifting ordering: from II $>$ IV $>$ I to IV $>$ I $>$ II.

The clone receiving the most damage, replicate $\mathrm{V}$, was exposed longest to direct sunlight (Fig. 1) and had the highest average level of glucosinolates $(2.19 \mathrm{mg} / \mathrm{g})$. Clones in the open are phenologically advanced (Fig. 4), having longest exposure to direct sun and thus earliest snow melt. Early growth, such as by plants in the open, coincides with early insect activity and leads to increased leaf damage (Collinge and Louda 1989). Also, clones in the open have been found to be generally more vulnerable to water deficit stress (S. M. Louda, unpublished manuscript). Insect damage also varies between plants across small-scale habitat discontinuities, such as a sun/shade transition (Louda and Rodman $1983 a, b$ ), or along short soil-moisture gradients (Louda 1988). So, the magnitudes of both insect herbivory and stress induced by our treatment were related to the clone's specific position within the environment.

These results combine with earlier ones to suggest that a substantial heterogeneity in the intensity interaction of plants with their adapted insects occurs within bittercress populations. In fact, heterogeneity in use generally characterizes the field data on insect herbivory in plant populations (see Harper 1977, Crawley 1983, Louda 1988). Such variation is often consistent and spatially ordered (e.g., Louda 1982, 1983). We propose that environmentally related physiological variation among plants within a plant population often disproportionately distributes insect herbivory onto a predictable subset of the individuals in that population.

Spatially explicit patterns of differential damage by insects have demographic, distributional and, potentially, evolutionary consequences (Louda 1982). First, since herbivory can significantly decrease growth and reproduction of bittercress (Louda 1984), the demographic consequences are straight-forward. The relative contribution of stressed individuals to the next generation will be decreased. And, when plants in one part of the environmental mosaic suffer dispropor- 
tionately, as in this case, then the distribution of plants in the population is likely to be altered, and often reduced, from its potential distribution (Louda 1982, 1983). Finally, when there is a spatial pattern in the occurrence of stress, and thus reduced plant resistance to insect herbivory, the genotypes in one portion of the habitat will contribute less to the next generation. This effect should be amplified by the fact that genetic relatedness is often spatially correlated in plants (see Harper 1977). Spatially arrayed, differential contributions among genotypes will alter population structure, and create the potential for microevolution and local differentiation.

Thus, our study illustrates significant indirect effects of environmental variation. We found physical environmental differences, such as those that induce differences in water deficit stress, could modify plant physiological status and create a predictable, spatially explicit pattern of insect herbivore damage to plants. Since such variation in insect herbivore-plant interactions has major demographic, distributional and evolutionary implications, further examination of this hypothesis is warranted.

\section{ACKNOWLEDGMENTS}

We are grateful to the many people who have helped us on this project. In particular, we thank: J. E. Rodman and F. S. Chew for stimulating discussions of crucifer biology; N. Cobb, M. Crawley, L. R. Fox, D. H. Janzen, A. Joern, K. H. Keeler, J. Maschinski, P. A. Morrow, M. V. Price, P. W. Price, and N. M. Waser for insightful commentary on various versions of the manuscript; M. Bishop, J. T. Smith, and R. W. Otley for energetic assistance with specific aspects of the data collection and analysis; D. Grimaldi, B. C. Ratcliffe, D. Smith, G. C. Steyskal, S. White, and D. Whitehead, for taxonomic aid with the insects; J. McClendon, E. Davies, P. R. Rundel, and $\mathrm{P}$. W. Barnes for advice on measurement or interpretation of physiological data; F. W. Wagner, R. L. Pardy, R. S. de la Motte, G. Sarath, J. Stratton, and M. A. Blua for involvement in the chemical analyses of plant tissues; C. D. Langefeld, W. W. Stroup, J. A. Wilson, and an anonymous reviewer for statistical advice; and, S. Gaines and L. S. Vescio for help with graphics. It is a pleasure to acknowledge support for work on bittercress by: the National Science Foundation (grants DEB82-07955, BSR84-05625, BSR85-16515), Sigma Xi (Grant-in-Aid), University of Nebraska (School of Biological Sciences: L. B. and E. R. Walker \& Jessie Lee Funds) and the Rocky Mountain Biological Laboratory (Graduate Research Scholarship to S. K. Collinge).

\section{Literature Cited}

Barrell, J. 1969. Flora of the Gunnison Basin: Gunnison, Saguache and Hinsdale Counties, Colorado. Natural Land Institute, Rockford, Illinois, USA.

Baskin, C. C., and J. M. Baskin. 1974. Responses of Castragalus tennesseensis to drought: changes in free amino acids and amides during water stress and possible ecological significance. Oecologia (Berlin) 17:11-16.

Bazzaz, F. A., N. R. Chiariello, P. D. Coley, and L. F. Pitelka. 1987. Allocating resources to reproduction and defense. BioScience 37:58-67.

Bermner, J. M. 1966. Total nitrogen. Agronomy 9:11491178.

Bernays, E. A., and A. C. Lewis. 1986. The effect of wilting on palatability of plants to Schistocerca gregaria, the desert locust. Oecologia (Berlin) 70:132-135.

Blua, M. J. 1984. Glucosinolate variation in Isomeris (Cappariaceae). Thesis. San Diego State University, San Diego, California, USA.

Blua, M. J., and Z. Hanscom, III. 1986. Isolation and characterization of glucocapparin in Isomeris arborea Nutt. Journal of Chemical Ecology 12:1449-1458.

Bonnemaison, L. 1965. Insect pests of crucifers and their control. Annual Review of Entomology 10:207-232.

Bowers, M. D. 1988. Chemistry and coevolution: iridoid glycosides, plants and herbivorous insects. Pages 133-166 in $\mathrm{K}$. C. Spencer, editor. Chemical mediation of coevolution. Academic Press, New York, New York, USA.

Boyer, J. S. 1982. Plant productivity and the environment. Science 218:443-448.

Bradford, K. J., and T. C. Hsiao. 1982. Physiological responses to moderate water stress. Pages 263-324 in O. L. Lange, P. S. Nobel, C. B. Osmond, and H. Ziegler, editors. Encyclopedia of plant physiology. New Series, Volume 12. Springer-Verlag, Berlin, Germany.

Bultman, T. L., and S. H. Faeth. 1986. Leaf size selection by leaf-mining insects on Quercus emoryi (Fagaceae). Oikos 46:311-316.

Cataldo, D. A., M. Haroon, L. E. Schrader, and V. L. Youngs. 1975. Rapid colorimetric determination of nitrate in plant tissue by nitration of salicylic acid. Communications in Soil Science and Plant Analysis 6:71-80.

Cates, R. G., and H. Alexander. 1982. Host resistance and susceptibility. Pages 212-263 in J. B. Mitton and K. B. Sturgeon, editors. Bark beetles in North American conifers: a system for the study of evolutionary biology. University of Texas Press, Austin, Texas, USA.

Cates, R. G., and R. A. Redak. 1988. Variation in the terpene chemistry of douglas-fir and its relationship to western spruce budworm success. Pages 317-344 in K. C. Spencer editor. Chemical mediation of coevolution. Academic Press, New York, New York, USA.

Cates, R. G., R. A. Redak, and C. B. Henderson. 1983. Patterns in defensive natural product chemistry: douglas fir and western spruce budworm interactions. Pages 5-19 in P. A. Hedin, editor. Plant resistance to insects. American Chemical Society Symposium Series, Number 208. American Chemical Society, Washington, D.C., USA.

Chew, F. S. 1975. Coevolution of pierid butterflies and their cruciferous host plants. I. The relative quality of available resources. Oecologia (Berlin) 20:117-127.

- 1977. Coevolution of pierid butterflies and their cruciferous foodplants. II. The distribution of eggs on potential foodplants. Evolution 31:568-579.

. 1988. Biological effects of glucosinolates. Pages 155181 in H. G. Cutler, editor. Biologically active natural products: potential uses in agriculture. American Chemical Society Symposium Series, Number 380. American Chemical Society, Washington, D. C., USA.

Coley, P. D., J. P. Bryant, and F. S. Chapin, III. 1985. Resource availability and plant antiherbivore defense. Science 230:895-899.

Collinge, S. K., and S. M. Louda. 1988a. Patterns of resource use by a drosophilid (Diptera) leaf miner on a native crucifer. Annals of the Entomological Society of America 81: 733-741.

Collinge, S. K., and S. M. Louda. 1988b. Herbivory by leaf miners in response to experimental shading of a native crucifer. Oecologia (Berlin) 75:559-566.

Collinge, S. K., and S. M. Louda. 1989. Influence of plant phenology on the insect herbivore/bittercress interaction. Oecologia (Berlin) 79:111-116.

Crawley, M. J. 1983. Herbivory: the dynamics of animalplant interactions. University of California Press, Berkeley, California, USA. 
Dale, D. 1988. Plant-medicated effects of soil mineral stresses on insects. Pages 35-110 in E. A. Heinrichs, editor. Plant stress-insect interactions. John Wiley \& Sons, New York, New York, USA.

Denno, R. F., and M. S. McClure, editors. 1983. Variable plants and herbivores in natural systems. Academic Press, New York, New York, USA.

Edwards, P. J., and S. D. Wratten. 1983. Ecology of insectplant interactions. Edward Arnold, London, England.

English-Loeb, G. M. 1989. Nonlinear responses of spider mites to drought-stressed plants. Ecological Entomology 14: 45-55.

Faeth, S. H. 1988. Plant-mediated interactions between seasonal herbivores: enough for evolution or coevolution? Pages 391-414 in K. C. Spencer, editor. Chemical mediation of coevolution. Academic Press, New York, New York, USA.

Feeny, P. 1977. Defensive ecology of the Cruciferae. Annals of the Missouri Botanic Garden 64:221-234.

Fitter, A. H., and R. K. M. Hay. 1981. Plant physiological ecology. Academic Press, New York, New York, USA.

Fox, L. R., and B. J. Macauley. 1977. Insect grazing on Eucalyptus in response to variation in leaf tannins and nitrogen. Oecologia (Berlin) 29:145-162.

Gates, C. T. 1964. The effect of water stress on plant growth. Journal of the Austrialian Institute of Agricultural Science 30:3-22.

Gershenzon, J. 1984. Changes in the levels of plant secondary metabolites under water and nutrient stress. Pages 273-320 in B. N. Timmerman, C. Steelink, and F. A. Loewus, editors. Phytochemical adaptations to stress. Recent Advances in Phytochemistry 18.

Gershenzon, J., D. E. Lincoln, and J. H. Langenheim. 1978. The effect of moisture stress on monoterpenoid yield and composition in Satureja douglasii. Biochemical Systematics and Ecology 6:33-43.

Haglund, B. M. 1980. Proline and valine: cues which stimulate grasshopper herbivory during drought stress. Nature 288:697-698.

Hansen, A. D., and W. D. Hitz. 1983. Whole-plant response to water deficits: water deficits and nitrogen economy. Pages 331-343 in H. M. Taylor, W. R. Jordan, and T. R. Sinclair, editors. Limitations to efficient water use in crop production. American Society of Agronomy, Madison, Wisconsin, USA.

Harper, J. L. 1977. The population biology of plants. Academic Press, New York, New York, USA.

Harrington, H. D. 1954. Manual of the plants of Colorado. Sage, Denver, Colorado, USA.

Hartnett, D. C., and F. A. Bazzaz. 1983. Physiological integration among intraclonal ramets in Solidago canadensis. Ecology 64:779-788.

Heinrichs, E. A., editor. 1988. Plant stress-insect interactions. John Wiley \& Sons, New York, New York, USA.

Hicks, K. L., and J. O. Tahvanainen. 1974. Niche differentiation by crucifer-feeding flea beetles (Coleoptera: Chrysomelidae). American Midland Naturalist 91:406-423.

Holtzer, T. O., T. L. Archer, and J. M. Norman. 1988. Host plant suitability in relation to water stress. Pages 111-138 in E. A. Heinrichs, editor. Plant stress-insect interactions. John Wiley \& Sons, New York, New York, USA.

Hsiao, T. C. 1973. Plant responses to water stress. Annual Review of Plant Physiology 24:519-570.

Hsiao, T. C., E. Acevedo, E. Fereres, and D. W. Henderson. 1976. Stress metabolism: water stress, growth and osmotic adjustment. Philosophical Transactions of the Royal Society of London 273:479-500.

Hsiao, T. C., and K. J. Bradford. 1983. Physiological consequences of cellular water deficits. Pages 227-265 in $\mathrm{H}$. M. Taylor, W. R. Jordan, and T. R. Sinclair, editors. Limitations to efficient water use in crop production. American Society of Agronomy, Madison, Wisconsin, USA.
Hughes, P. R. 1988. Insect populations on host plants subjected to air pollution. Pages 249-319 in E. A. Heinrichs, editor. Plant stress-insect interactions. John Wiley \& Sons, New York, New York. USA.

Hughes, P. R., A. I. Dickie, and M. A. Penton. 1983. Increased success of the Mexican bean beetle on field-grown soybeans exposed to sulfur dioxide. Journal of Environmental Quality 12:565-568.

Hughes, P. R., J. E. Potter, and L. H. Weinstein. $1982 a$. Effects of air pollution on plant-insect interactions: increased susceptibility of greenhouse grown soybeans to the Mexican bean beetle after plant exposure to $\mathrm{SO}_{2}$. Environmental Entomology 11:173-176.

Hughes, P. R., L. H. Weinstein, J. A. Laurence, R. F. Sacher, A. I. Dickie, and L. M. Johnson. 1982b. Modification of insect-plant relations by plant stress. Pages $445-446$ in J. H. Visser and A. K. Minks, editors. Proceedings of the Fifth International Symposium on Insect-Plant Relationships. PUDOC, Wageningen, The Netherlands.

Isaac, R. A., and W. G. Johnson. 1976. Determination of total nitrogen in plant tissue, using a block digestor. Journal of the Association of Analytical Chemists 59:98-100.

Janzen, D. H. 1974. Tropical blackwater rivers, animals and mast fruiting by the Dipterocarpaceae. Biotropica 6:69103.

Jones, C. G., and J. S. Coleman. 1991. Plant "stress" and insect herbivory: toward an integrated perspective. In $\mathrm{H}$. A. Mooney, W. E. Winner, and E. J. Pell, editors. Integrated responses of plants to environmental stresses. Academic Press, New York, New York, USA, in press.

Josefsson, E. 1970. Glucosinolate content and amino acid composition of rapeseed (Brassica napus) meal as affected by sulfur and nitrogen nutrition. Journal of the Science of Food and Agriculture 21:98-103.

Kennedy, J. S. 1958. Physiological condition of the hostplant and susceptibility to aphid attack. Entomologia Experimentalis et Applicata 1:50-65.

Kennedy, J. S., K. P. Lamb, and C. O. Booth. 1958. Responses of Aphis fabae Scop. to water shortage in hostplants in pots. Entomologia Experimentalis et Applicata 1:274 291.

Kozlowski, T. T. 1968. Water deficits and plant growth Volume I. Academic Press, New York, New York, USA. , editor. 1984. Flooding and plant growth. Academic Press, New York, New York, USA.

Kramer, P. J. 1983. Water relations of plants. Academic Press, New York, New York, USA

Langenheim, J. H. 1955. Flora of the Crested Butte Quadrangle, Colorado. Madroño 13:64-78.

-1962. Vegetation and environmental patterns in the Crested Butte area, Gunnison County, Colorado. Ecological Monographs 32:249-285.

Levitt, J. 1972. Responses of plants to environmental stress. Academic Press, New York, USA.

Lewis, A. C. 1979. Feeding preference for diseased and wilted sunflower in the grasshopper, Melanoplus differentialis. Entomologia Experimentalis et Applicata 26:202-207.

- 1984. Plant quality and grasshopper feeding: effects of sunflower condition on preference and performance in Melanoplus differentialis. Ecology 65:836-843.

Louda, S. M. 1982. Distribution ecology: variation in plant recruitment over a gradient in relation to insect seed predation. Ecological Monographs 52:25-41.

1983. Seed predation and seedling mortality in the recruitment of a shrub, Haplopappus venetus (Asteraceae), along a climatic gradient. Ecology 64:511-521.

- 1984. Herbivore effect on stature, fruiting and leaf dynamics of a native crucifer. Ecology 65:1379-1386.

1986. Insect herbivory in response to root-cutting and flooding stress on a native crucifer under field conditions. Acta Oecologia, Oecologia Generalis 7:37-53. 
1988. Insect pests and plants stress as considerations for revegetation of disturbed ecosystems. Pages 51-67 in J. Cairns, editor. Rehabilitating damaged ecosystems. Volume 2. CRC Press, Boca Raton, Florida, USA.

Louda, S. M., P. Dixon, and N. Huntly. 1987a. Herbivory in sun versus shade at a natural meadow-woodland ecotone in the Rocky Mountains. Vegetatio 72:141-149.

Louda, S. M., M. Farris, and M. J. Blua. 1987b. Variation in methylglucosinolate and insect damage to Cleome serrulata (Capparaceae) along a natural soil moisture gradient. Journal of Chemical Ecology 13:569-581.

Louda, S. M., N. Huntly, and P. Dixon. 1987c. Insect herbivory across a sun/shade gradient: response to experimentally-induced in situ plant stress. Acta Oecologia, Oecologia Generalis 8:357-363.

Louda, S. M., K. H. Keeler, and R. D. Holt. 1990. Herbivore influences on plant performance and competitive interactions. Pages 413-444 in J. B. Grace and D. Tilman, editors. Perspectives in plant competition. Academic Press, New York, New York, USA.

Louda, S. M., and S. Mole. 1992. Glucosinolates: chemistry and ecology. In G. A. Rosenthal and M. R. Berenbaum, editors. Herbivores, their interactions with secondary plant metabolites. Second edition. Volume I. Academic Press, New York, New York, USA, in press.

Louda, S. M., and J. E. Rodman. 1983a. Ecological patterns in the glucosinolate content of a native mustard, Cardamine cordifolia, in the Rocky Mountains. Journal of Chemical Ecology 9:397-422.

Louda, S. M., and J. E. Rodman. 1983b. Concentration of glucosinolates in relation to habitat and insect herbivory for the native crucifer Cardamine cordifolia. Biochemical Systematics and Ecology 11:199-207.

Mattson, W. J. 1980. Herbivory in relation to plant nitrogen content. Annual Review of Ecology and Systematics 11: 119-161.

Mattson, W. J., and R. A. Haack. 1987a. The role of drought in the outbreaks of plant-eating insects. BioScience 37:110 118.

Mattson, W. J., and R. A. Haack. 1987b. The role of drought stress in provoking outbreaks of phytophagous insects. Pages 365-407 in P. Barbosa and J. Schultz, editors. Insect outbreaks: ecological and evolutionary perspectives. Academic Press, Orlando, Florida, USA.

McClure, M. S. 1980. Foliar nitrogen: a basis for host suitability for elongate hemlock scale, Fiorinia externa (Homoptera: Diaspididae). Ecology 61:72-79.

McKey, D. M. 1979. The distribution of secondary compounds within plants. Pages 55-133 in G. A. Rosenthal and D. H. Janzen, editors. Herbivores: their interaction with secondary metabolites. Academic Press, New York, New York, USA.

McNeill, S. 1973. The dynamics of a population of Leptoptera dolabrata (Heteroptera: Miridae) in relation to its food resources. Journal of Animal Ecology 42:495-507.

McNeill, S., and T. R. E. Southwood. 1978. The role of nitrogen in the development of insect/plant relationships. Pages 77-98 in J. B. Harborne, editor. Biochemical aspects of plant and animal coevolution. Academic Press, New York, New York, USA.

Miles, P. W., D. Aspinall, and L. Rosenberg. 1982a. Performance of the cabbage aphid, Brevicoryne brassicae (L.), on water-stressed rape plants, in relation to the changes in their chemical composition. Australia Journal of Zoology 30:337-345.

Miles, P. W., D. Aspinall, and L. Rosenberg. 1982b. The performance of two chewing insects on water-stressed food plants in relation to changes in their chemical composition. Australian Journal of Zoology 30:347-355.

Moore, S., and W. H. Stein. 1954. A modified ninhydrin reagent for the photometric determination of amino acids and related compounds. Journal of Biological Chemistry 211:907-913.

Myers, J. H. 1985. Effect of physiological condition of the host plant on the ovipositional choice of the cabbage white butterfly, Pieris rapae. Journal of Animal Ecology 54:193204.

National Oceanic and Atmospheric Administration (NOAA) 1969-1985. Climatological data. Superintendent of Documents, United States Government Printing Office, Washington, D.C., USA.

Neil, L. J., and B. Bible. 1972. Thiocyanate ion $\left(\mathrm{SCN}^{-}\right)$ content of hypocotyl-root region of Raphanus sativus as affected by environment. Journal of the Science of Food and Agriculture 23:1379-1382.

Nobel, P.S. 1983. Biophysical plant physiology and ecology. W. H. Freeman, New York, New York, USA.

Oka, I. N., and D. Pimentel. 1976. Herbicide (2,4-D) increases insect and pathogen pests on corn. Science 193:239240.

Osmond, C. B., M. P. Austin, J. A. Berry, W. D. Billings, J. S. Boyer, J. W. H. Dacey, P. S. Nobel, S. D. Smith, and W. E. Winner. 1987. Stress physiology and the distribution of plants. BioScience 37:38-48.

Pimentel, D. 1961. An evaluation of insect resistance in broccoli, brussels sprouts, cabbage, collards, and kale. Journal of Economic Entomology 54:156-158.

Redak, R. A., and R. G. Cates. 1984. Douglas fir-spruce budworm interactions: the effect of nutrition, chemical defenses, tissue phenology, and tree physical parâmeters on budworm success. Oecologia (Berlin) 62:61-67.

Rhoades, D. 1983. Herbivore population dynamics and plant chemistry. Pages 155-220 in R. F. Denno and M. S. McClure, editors. Variable plants and herbivores in natural and managed systems. Academic Press, New York, New York, USA.

- 1985. Offensive-defensive interactions between herbivores and plants: their relevance in herbivore population dynamics and ecological theory. American Naturalist 125:205-238.

Rodman, J. E. 1978. Glucosinolates: methods of analysis and some chemosystematic problems. Phytochemical Bulletin 11:6-13.

Rodman, J. E., and S. M. Louda. 1984. Phenology of glucosinolate concentrations in roots, stems and leaves of Cardamine cordifolia. Biochemical Systematics and Ecology 12:37-46.

Rodman, J. E., and S. M. Louda. 1985. Seasonal flux of isothiocyanate-yielding glucosinolates in roots, stems and leaves of Cardamine cordifolia. Biochemical Systematics and Ecology 13:405-412.

Root, R. B. 1973. Organization of a plant-arthropod association in simple and diverse habitats: the fauna of collards (Brassica oleracea). Ecological Monographs 43:95-124.

Scholander, P. F., H. T. Hammel, E. D. Bradstreet, and E. A. Hemmingsen. 1965. Sap pressure in vascular plants. Science 148:339-345.

Scriber, J. M. 1984. Host plant suitability. Pages 159-202 in W. J. Bell and R. T. Carde, editors. Chemical ecology of insects. Sinauer, Sunderland, Massachusetts, USA.

Scriber, J. M., and F. Slansky, Jr. 1981. The nutritional ecology of immature insects. Annual Review of Entomology 26:183-211.

Slansky, F., and J. G. Rodriguez, editors. 1987. Nutritional ecology of insects, mites, spiders and related invertebrates. John Wiley \& Sons, New York, New York, USA.

Slansky, F., and J. M. Scriber. 1985. Food consumption and utilization. Pages 87-163 in G. A. Kerkut and L. I. Gilbert, editors. Comprehensive insect physiology, biochemistry, and pharmacology. Volume 4. John Wiley \& Sons, New York, New York, USA.

Smith, D. 1969. Removing and analyzing total non-struc- 
tural carbohydrates from plant tissue. Research Department, University of Wisconsin College of Agriculture and Life Sciences, Madison, Wisconsin, USA.

Sokal, R. R., and F. J. Rohlf. 1981. Biometry. W. H. Freeman, San Francisco, California, USA.

Thompson, J. N. 1988. Variation in interspecific interactions. Annual Review of Ecology and Systematics 19:6587.

Thorsteinson, A. J. 1960. Host selection in phytophagous insects. Annual Review of Entomology 5:193-218.

Tingey, W. M., and S. R. Singh. 1980. Environmental factors influencing the magnitude and expression of resistance. Pages 87-113 in F. G. Maxwell and P. R. Jennings, editors. Breeding plants resistant to insects. Wiley, New York, New York, USA.

Turner, N. C., and P. J. Kramer, editors. 1980. Adaptation of plants to water and high temperature stress. Wiley-Interscience, New York, New York, USA.

van Emden, H. F., and M. A. Bashford. 1968. A comparison of the reproduction of Brevicoryne brassicae and Myzus persicae in relation to soluble nitrogen concentration and leaf age (leaf position) in the Brussels sprout plant. Entomologia Experimentalis et Applicata 12:351-364.

van Emden, H. F., and M. A. Bashford. 1971. The performance of Brevicoryne brassicae and Myzus persicae in relation to plant age and leaf amino acids. Entomologia Experimentalis et Applicata 14:349-360.

Waring, G. L., and P. W. Price. 1988. Consequences of host plant chemical and physical variability to an associated herbivore. Ecological Research 3:205-216.

Wearing, C. H. 1972a. Responses of Myzus persicae and Brevicoryne brassicae to leaf age and water stress in Brussels sprouts grown in pots. Entomologia Experimentalis et Applicata 15:61-80. 1972b. Selection of Brussels sprouts of different water status by apterous and alate Myzus persicae and Brevicoryne brassicae in relation to the age of leaves. Entomologia Experimentalis et Applicata 15:139-154.

Wearing, C. H., and H. F. van Emden. 1967. Studies on the relations of insect and host plant. I. Effects of water stress in host-plants in pots on infestation by Aphis fabae Scop., Myzus persicae (Sulz.) and Brevicoryne brassicae (L.). Nature 213:1051-1052.

White, T. C. R. 1969. An index to measure weather-induced stress of trees associated with outbreaks of psyllids in Australia. Ecology 50:905-909.

. 1974. A hypothesis to explain outbreaks of looper caterpillars, with special reference to populations of Selidosema suavis in a plantation of Pinus radiata in New Zealand. Oecologia (Berlin) 16:279-301.

1976. Weather, food and plagues of locusts. Oecologia (Berlin) 22:119-134.

. 1978. The importance of a relative shortage of food in animal ecology. Oecologia (Berlin) 33:71-86.

. 1984. The abundance of invertebrate herbivores in relation to the availability of nitrogen in stressed food plants. Oecologia (Berlin) 63:90-105.

Wilkinson, L. 1986. SYSTAT, the system for statistics. SYSTAT, Evanston, Illinois, USA.

Wolfson, J. L. 1980. Oviposition response of Pieris rapae to environmentally induced variation in Brassica nigra. Entomologia Experimentalis et Applicata 27:223-232.

1982. Developmental responses of Pieris rapae and Spodoptera eridania to environmentally induced variation in Brassica nigra. Environmental Entomology 11:207-213. 